\title{
51. ZJAZD STUDIORUM NOVI TESTAMENTI SOCIETATIS (STRASBURG 1996)
}

W dniach od 6. do 16. sierpnia 1996 r. miał miejsce w Strasburgu 51. zjazd organizacji Studiorum Novi Testamenti Societas (SNTS).

Stroną organizacyjną zjazdu zajęły się dwa wydziały teologiczne Uniwersytetu w Strasburgu: protestancki i katolicki. Tradycja szkolnictwa akademickiego w Strasburgu sięga czasów Reformacji, kiedy to w r. 1523 Martin Bucer założył szkołę teologiczną w duchu reformatorskim. Szkoła ta została przekształcona w akademię (1566-1621), aby stać się wreszcie uniwersytetem $\mathrm{z}$ wydziałem teologii protestanckiej. Katolicki wydział teologiczny działa od $1903 \mathrm{r}$. Znane nazwiska biblistów pojawiają się w historii tych dwóch wydziałów teologicznych. Wspomnijmy niektóre: A. Schweitzer, J. Héring, O. Cullmann (ur. 1902 i żyjący dotąd), H. Clavier, M.-A. Chevallier, J. Schmitt, E. Trocmé i inni. Ale wróćmy do zjazdu.

W programie były przewidziane trzy typy spotkań i komunikacji naukowej: wykłady głowne (Main Papers), wykłady krótsze (Short Papers) i seminaria.

Inauguracyjny wykład główny (Presidential Address) wygłosił przewodniczący zjazdu, G. N. Stanton nt. „Czteroksztaltne Ewangelie”.

Inne wykłady główne:

- D. Hellholm, „Funkcja argumentacyjna $\mathrm{Rz} 7,1-6$ ”;

- J. Delorme, "Ewangelia i opowiadanie. Narracja ewangeliczna u Mk (narratologia i semiotyka opowiadania ewangelicznego)";

- S. Kim „Jeszcze o 'misterium' w Rz 11, 25n;

- P. Lampe, Socjologiczne zbliżenie do Nowego Testamentu.

A oto wykłady krótsze, z których niektóre były równoległe (Simultaneous Short Papers), co stwarzalo dylematy, który wybrać:

- M. Wolter, „Etos i identyczność we wspólnotach pawłowych”; $58-62)$;

- M. Philonenko, „Na zewnątrz psy i guślarze” (Ap 22, 15 i 4Q MMT B

- H. Kvalbein, „Cuda na końcu czasu: uwagi do 4Q 521”;

- C. von Wahlde, „Perykopa o Samarytance. Synoptycy i cuda u Jana: sprawa kryteriów";

- B. Witherington, „Klaudiusz, Żydzi a Religio licita”;

-D. P. Moessner, „Kryteria dla autentycznej historiografii na przykładzie Lk 1, 3";

- R. B. Ward, „Uwagi na temat Rz 1, 26n”.

Z imprez kulturalno-towarzyskich uczestnicy zjazdu SNTS w stolicy Alzacji będą mile wspominać koncert Son et Lumière w słynnej katedrze, zwiedzanie przy pomocy stateczków Starego Miasta, wizytę w instytucjach 
europejskich (Parlament europejski), przyjęcie wydane przez Radę Miejską w pawilonie Józefiny czy koncert kwartetu Florestan i kościele Saint Guillaume. Dla chętnych były wycieczki, na przykład w okolice rodzinne Alberta Schweitzera: do Kaysersbergu - miejsca jego urodzin i do Gunsbach, gdzie mieści się muzeum A. Schweitzera i muzeum afrykańskie, lub do Colmaru, aby zwiedzić znane muzeum Unterlinden.

Lista uczestników zjazdu strasburskiego obejmowała w fazie końcowej 401 osób: wliczono w to, oprócz samych uczestników, także i towarzyszących im członków rodzin. Nie można biblistów żyjących w rodzinach pozbawiać ich naturalnego otoczenia, zwłaszcza w czasie wakacji: dla wielu bowiem zjazdy naukowe są formą spędzania urlopu. A poza tym egzegeza Biblii nie jest zarezerwowana tylko dla celibatariuszy.

Strasburg tworzy niepowtarzalną atmosfere miasta europejskiego, dwujęzycznego, dwuwyznaniowego, praktycznie ekumenicznego, $\mathrm{z}$ bogatą tradycją kulturalno-teologiczną (pamiętajmy o mistyce renańskiej). Powstające nowoczesne bloki nie przesłaniają wieży strasburskiej katedry, a śmiałe konstrukcje i aranżacje nie niszczą sympatycznych starych zaułków i pomieszczeń. Oto czego potrzeba zjednoczonej Europie: mądrości „ojca rodziny, który ze swego skarbca wydobywa rzeczy nowe i stare" (Mt 13, 52).

Kraków

KS. JERZY CHMIEL

\section{Ks. Stanisław Pisarek}

\section{COLLOQUIUM BIBLICUM (WIEDEŃ 1996)}

Mimo odejścia na emeryturę profesora Jakuba Kremera (Wydział Teologii Katolickiej, Uniwersytet Wiedeński) kolokwia biblijne urządzane co dwa lata pod jego egidą w stolicy Austrii są kontynuowane pod nowym kierownictwem. Nowym liderem tej naukowej imprezy o charakterze międzynarodowym jest profesor Gottfried Vanoni SVD z Akademii Teologicznej St. Gabriel w Mödling koło Wiednia. Pełni on zarazem funkcję przewodniczącego Rady Naukowej przy Austriackim Katolickim Towarzystwie Biblijnym (Österreichisches Katholisches Bibelwerk = ÖKB, które tę imprezę w głównej części sponsoruje, jako że jest ona rozumiana jako promocja dla biblistów z krajów w Europie Centralnej i Wschodniej). Europa Wschodnia była na Colloquium reprezentowana w osobie ks. Janusza Czerskiego (WT na Uniwersytecie Opolskim), który wykłada zarazem Pismo święte we Lwowie u katolików obrządku bizantyńskiego, uważając się za Ukraińca. Wszystkich uczestników było na liście 55, najwięcej z Polski (15). Pozostali z krajów: Austria z Południowym Tyrolem (Italia) i Niemcy (dawniejsze Wschodnie) jako gospodarze wobec kolegów z Europy Centralnej - z krajów 